\title{
Improvement the Corrosion Resistance for the Galvanized Steel by Adding Sn
}

\author{
Z. Abdel Hamid11,, S. S. Abd El Rehim², A. Abou Shama3 ${ }^{3}$ M. Ebrahim ${ }^{3}$ \\ ${ }^{1}$ Central Metallurgical Research \& Development Institute (CMRDI), Cairo, Egypt \\ ${ }^{2}$ Chemical Department, Faculty of Science, Ain Shams University, Cairo, Egypt \\ ${ }^{3}$ Physics Department, Faculty of Science, Ain Shams University, Cairo, Egypt \\ Email: *forzeinab@yahoo.com; rehimth@hotmail.com; aboushamaali@yahoo.com; ma856sa@hotmail.com
}

Received 1 March 2016; accepted 18 April 2016; published 21 April 2016

Copyright (C) 2016 by authors and Scientific Research Publishing Inc.

This work is licensed under the Creative Commons Attribution International License (CC BY).

http://creativecommons.org/licenses/by/4.0/

(c) (i) Open Access

\section{Abstract}

The chemical composition of the zinc bath can strongly influence on the hot-dip galvanized coatings. In this work, the effects of tin addition on the surface morphology, and the corrosion resistance of hot-dip galvanized steel were investigated. The corrosion behavior of steel samples galvanized with zinc and $\mathrm{Zn}-\mathrm{Sn}$ alloys containing different $\mathrm{wt} \% \mathrm{Sn}$ was analyzed by various corrosion tests such as potentiodynamic polarization Tafel lines and electrochemical impedance spectroscopy (EIS) techniques. Salt spray test was employed in order to study the corrosion products of the specimens. Surface morphology, the composition of coating layers and nature of the corrosion products were also investigated using field emission scanning electron microscopy (FE-SEM), energy dispersive X-ray analysis (EDX) and X-Ray diffraction (XRD) techniques, respectively. The results indicated that the addition of small amounts of Sn $(0.1 \mathrm{wt} \%)$ to the molten zinc galvanizing bath can improve the corrosion resistance of hot-dip galvanized steel.

\section{Keywords}

Hot-Dip Galvanizing Process, Corrosion, Potentiodynamic Polarization, EIS, Salt Spray

\section{Introduction}

Metals play an important role in our everyday life. Steel has always been the most favored and widely used material because of their excellent strength, formability, the economics of production, and the ability to recycle indefinitely. However, it tends to react with agents in the atmosphere to form stable bonds-ferrous oxides and

${ }^{*}$ Corresponding author.

How to cite this paper: Abdel Hamid Z., Abd El Rehim, S.S., Abou Shama, A. and Ebrahim, M. (2016) Improvement the Corrosion Resistance for the Galvanized Steel by Adding Sn. Journal of Surface Engineered Materials and Advanced Technology, 6, 58-71. http://dx.doi.org/10.4236/isemat.2016.62006 
salts. The rate of these reactions depends on the nature and concentration of the corrosive agents present in the environment. Hence, most of the energies and research have been involved in reducing corrosion of steel. The most popular and most widely process used for corrosion protection of steel is galvanizing [1] [2]. Enhancing life of galvanized products results in the reduction in maintenance and replacement costs, thereby large savings in energy. The galvanized coating provides protection to the substrate through the formation of a physical barrier, separating the corroding atmosphere from the substrate, which is more commonly known as "barrier protection", where Zn being lower in the galvanic series than Fe, so it corrodes preferentially, thus protecting the substrate [3].

In hot dip galvanizing process, several parameters such as chemical composition of carbon steel and chemical composition of coating bath could affect the microstructure and properties of coatings [4]. Alloying elements added to $\mathrm{Zn}$ bath induce differences in the morphology of coatings through interface reactions. To improve the quality and the nature of the galvanized coating of $\mathrm{Zn}$ on steel, alloying elements, such as lead, aluminum, nick$\mathrm{el}$, and magnesium are added to the galvanized bath. Moreover, $\mathrm{Zn}-\mathrm{Pb}, \mathrm{Zn}-\mathrm{Al}, \mathrm{Zn}-\mathrm{Al}-\mathrm{Mg}$, and $\mathrm{Zn}-\mathrm{Fe}$ alloys are widely used to improve the quality of the galvanizing coatings [4] [5]. These alloying elements affect the crystallization, structure, and properties of the outer layer of the coatings. Depending on the type and concentration of the alloying addition in the galvanizing bath, some differences were induced in the crystallization process of the Fe-Zn phases [4].

The effect of lead on the galvanizing process has been studied by F. C. Porter, et al. [6]. The study proves that the addition of lead to the zinc in galvanizing bath promotes the formation of large, smooth surface spangles, which are having a good sacrificial ability. However, the optimum lead content requirement in the bath is from $1.0 \%$ to $1.5 \%$. It is also shown that the increase in chloride ion concentration reduces the effect of lead, but at a lower concentration of chloride the effect of lead is observed specially at $1.5 \% \mathrm{~Pb}$ addition.

A great attention is considered with respect to the role of aluminum (Al) in a $\mathrm{Zn}$ galvanizing bath. The effect of $\mathrm{Al}$ content on the structure and properties of the alloy layers have been investigated by Borzillo A.R et al. [7]-[18]. They proved that the morphology and the adherence of the layers of deposits were changed and depended on the $\mathrm{Al} \mathrm{wt} \%$ in the coating bath. The synergy of the excellent properties of $\mathrm{Zn}$ and $\mathrm{Al}$ has already been very well exploited by continuous galvanizers in commercial products like Galvalume ( $55 \mathrm{wt} \% \mathrm{Al})$ and Galfan $(5 \mathrm{wt} \% \mathrm{Al})$, which exhibit improved corrosion properties [11]. On the other hand, the effect of $\mathrm{Al}$ and $\mathrm{Mg}$ alloys has been illustrated by many studies [19]-[21]. Shiwei Li, et al. [20] studied the performance of a new type of hot-dip Zn-5Al-0.5Mg-0.08Si and Zn-5Al alloy coatings on the cold rolled common steel. It was found that, after adding $\mathrm{Mg}$ to the $\mathrm{Zn}-5 \mathrm{Al}$ coating, the corrosion products of $\mathrm{Zn}-5 \mathrm{Al}-0.5 \mathrm{Mg}-0.08 \mathrm{Si}$ coating is very compact and fine in size and adhere on the surface, so it can diminish the effect of the corrosion media. Also, $\mathrm{Pb}$ is an important additive for fluidizing the bath [22], but it is dangerous for human health and sometimes is replaced by tin (Sn). It has been added to give the galvanized coating improved spangle, brightness and ductility.

Additionally, the presence of $\mathrm{Sb}$ in the galvanizing bath has also led to improve the intergranular corrosion resistance [23]. The literature at present contains many reports about the effect of $\mathrm{Al}, \mathrm{Mg}, \mathrm{Pb}$ on $\mathrm{Zn}$ deposits, while, the reports about the influence of Sn on hot dip Zn coating is very limited [24] [25]. Sn and Sb have little effect on $\mathrm{Fe}-\mathrm{Zn}$ alloy formation, but at high concentration, $\mathrm{Sn}$ and $\mathrm{Sb}$ promoted spangle formation.

The goal of this research is to develop a new approach to improve the corrosion resistance of the galvanized pieces. To address this issue, different concentrations of Sn were added to the $\mathrm{Zn}$ galvanized bath and the effect of Sn addition on the galvanized samples was investigated. The structure of the galvanized layers and corrosion resistance of the $\mathrm{Zn}$ deposits in $3.5 \% \mathrm{NaCl}$ solution has been studied.

\section{Experimental Procedure}

Low carbon steel with thickness $0.6 \mathrm{~mm}$ was used in the experiment procedure. The chemical composition of the steel used in this study is shown in Table 1 . The steel sheets cannot be galvanized without preparation. The mechanical and chemical preparatory treatments determine the final appearance of the metal surface [26].

Table 1. Chemical composition of low carbon steel used as substrates for galvanizing process.

\begin{tabular}{cccccc}
\hline Element $\%$ & $\mathrm{C}$ & $\mathrm{Mn}$ & $\mathrm{P}$ & $\mathrm{Si}$ & $\mathrm{Fe}$ \\
\hline Low carbon steel (mild steel) & $0.15 \%$ & $0.6 \%$ & $0.028 \%$ & $0.08 \%$ & Balanced \\
\hline
\end{tabular}




\subsection{Mechanical Preparation}

The steel substrate was received in the form of sheets. Each sheet was cut into small specimens with dimensions $100 \times 50 \times 0.6 \mathrm{~mm}$. The samples were mechanically treated by emery paper of different grades up to 1200 grit to produce smooth surface without any scratch, rinsed with deionized water, cleaned ultrasonically in acetone, and finally dried in a stream of warm air.

\subsection{Chemical Preparation}

The chemical treatment is used to clean the metal surface from oils, impurities, soap residues and the natural oxide film, if required. This pretreatment includes the following steps:

1) Degreasing: The steel sheets were degreased for $5 \mathrm{~min}$. in a hot alkaline degreaser at $70^{\circ} \mathrm{C}$ for $5-10 \mathrm{~min}$. The chemical composition of the degreaser bath containing $20 \mathrm{~g} \cdot \mathrm{L}^{-1} \mathrm{Na}_{3} \mathrm{PO}_{4}, 20 \mathrm{~g} \cdot \mathrm{L}^{-1} \mathrm{NaOH}, 20 \mathrm{~g} \cdot \mathrm{L}^{-1} \mathrm{Na}_{2} \mathrm{CO}_{3}$ and surfactant. Oil, grease and dirt were properly removed. After this stage, the specimen was rinsed in running water then in distilled water.

2) Pickling: The steel sheets were pickled for $3 \mathrm{~min}$. at room temperature in $10 \% \mathrm{HCl}$ containing inhibitor 50 ppm Cetyl trimethyl ammonium bromide (CTAB) for the protection of metal surfaces and then the steel sheets were rinsed in water. The pickling process was used to remove any oxide from the steel surface.

3) Fluxing: The acid-cleaned steel sample is immersed in a flux solution maintained at about $65^{\circ} \mathrm{C}$ for approximately $5 \mathrm{~min}$. in a flux bath consisting of $500 \mathrm{~g} \cdot \mathrm{L}^{-1}$ of $\mathrm{ZnCl}_{2}, 50 \mathrm{~g} \cdot \mathrm{L}^{-1} \mathrm{NH}_{4} \mathrm{Cl}$, and $25 \mathrm{~mL}$ of $\mathrm{HCl}$ (laboratory grade) to maintain the $\mathrm{pH}$ level of $4-5$, then drying at $120^{\circ} \mathrm{C}$ before dipping in the molten $\mathrm{Zn}$ bath. The flux layer protects the cleaned metal surface from oxidation.

\subsection{Hot-Dip Galvanizing Process}

The zinc bath consists of zinc (purity of Zn $99.93 \mathrm{wt} \%$, from Egyptian Minerals Company) containing also Sn with different $\mathrm{wt} \%$ ranged from 0.1 to 0.5 . The sheets dipped in the zinc bath for $40 \mathrm{sec}$. and operated at $460^{\circ} \mathrm{C}$ $\pm 5^{\circ} \mathrm{C}$, then withdrawn at a controlled rate $\left(2 \mathrm{~cm} \cdot \mathrm{s}^{-1}\right)$ and carries with it an outer layer of molten zinc which solidifies to form the relatively pure outer zinc coating. When the cleaned and fluxed steel surface contacts the molten zinc of the galvanizing bath, the protective flux layer is removed leaving a clean steel surface which is immediately wetted by the zinc, this results in a reaction between zinc and steel with the formation of zinc-iron alloy layers. The galvanizing experiments were carried out in an electrically heated crucible furnace. The furnace has the following characteristics: 240 Volts, $2.6 \mathrm{~kW}, 11 \mathrm{Amp}, 50 / 60 \mathrm{~Hz}$ and the temperature range is $1200^{\circ} \mathrm{C}$ and has a graphite crucible. In order to have a better monitoring and control of the bath temperature, a K-type thermocouple was provided inside the furnace. A temperature-control console was provided with the temperature indicator.

\subsection{Coating Thickness Test}

The thickness of coatings was determined by electromagnetic thickness gauge (Thickness gauge 6000-N4). The thickness was measured in five different places on the specimen and the average value was taken.

\subsection{Field Emission-Scanning Electron Microscopy (FE-SEM) \& EDX}

The structures and the elemental analysis of the galvanized samples at different operating conditions were observed by Field emission scanning electron microscopy (FE-SEM, QUANTA EG) equipped with energy dispersive X-ray system (EDX), respectively.

\subsection{X-Ray Diffraction (XRD)}

XRD patterns were obtained over the diffraction ang $\cdot$ Le range $(2 \theta)$ of $4^{\circ}-80^{\circ}$ using an XRD (X'Pert PROPANalytical, Netherlands) diffractometer with $\mathrm{Cu} \mathrm{K} \alpha(\lambda=1.5404 \AA)$ radiation at a generator voltage of $45 \mathrm{kV}$ and a generator current of $30 \mathrm{~mA}$, with a step size of $0.02^{\circ}$ and a scan speed of $0.05 \mathrm{~s}^{-1}$.

\subsection{Corrosion Tests}

Three different corrosion tests were carried out by potentiodynamic polarization Tafel line; electrochemical im- 
pedance spectroscopy (EIS) and salt spray tests.

\subsubsection{Potentiodynamic Polarization Test}

The electrochemical measurements were performed using an IVIUMSTAT potentiostat-galvanostat operated under computer control. Electrochemical measurements were obtained in $3.5 \% \mathrm{NaCl}$ solution at $30^{\circ} \mathrm{C}$ using a three-electrode electrochemical cell. Before the measurements, the working electrode was degreased with acetone and rinsed with distilled water. The reference electrode that all potentials are referred was $\mathrm{Hg} / \mathrm{Hg}_{2} \mathrm{Cl}_{2} / \mathrm{Cl}^{-}$ saturated calomel electrode (SCE) of $E_{o}=240 \mathrm{mV}$ versus normal hydrogen electrode (NHE) and Pt wire was used as counter electrode. The time-voltage was recorded until the steady state potential was reached which is the open circuit potential $\left(\mathrm{E}_{\text {corr }}\right)$, the measurement was started from this potential first in the cathodic direction and then in the anodic direction.

\subsubsection{Electrochemical Impedance Spectroscopy Measurement (EIS)}

EIS was carried out in the frequency range of $35 \mathrm{kHz}-100 \mathrm{mHz}$ with an amplitude of $5 \mathrm{mV}$ sinusoidal potential using ac signals at the open circuit potential in $3.5 \% \mathrm{NaCl}$ media. The electrode potential was allowed to stabilize for $60 \mathrm{~min}$ before starting the measurement. All experiments were carried out in aerated solutions at a room temperature.

\subsubsection{Salt Spray Test}

Neutral salt spray test was performed according to ASTM B117 standard (ASTM B117, 2007) using ASCOT cabinet. The salt spray test was used to investigate the corrosion behavior of steel and galvanized steel in 3.5\% $\mathrm{NaCl}$ solution at room temperature.

\section{Results and Discussion}

\subsection{Characterization}

The effect of Sn concentrations in the molten $\mathrm{Zn}$ bath on the coating thickness and the thickness of the alloyed layers have been investigated as shown in Figure 1 and Table 2, respectively. The data of Figure 1 reveals that the coating thickness of the galvanized layer slightly increases with increasing Sn concentration from 0 to 0.3 $\mathrm{wt} \%$ and then, strongly increases in the thickness with increasing $\mathrm{wt} \% \mathrm{Sn}$. Table 2 illustrated that the thickness of the alloyed layer decreasing with Sn addition while, outer layer increasing. Moreover, Figure 2 shows the cross sectional structures of the traditional galvanized steel (Figure 2(a)) and galvanized steel obtained by immersing in a molten $\mathrm{Zn}$-Sn alloys containing different $\mathrm{wt} \% \mathrm{Sn}$ operated at $460^{\circ} \mathrm{C}$ for $40 \mathrm{~s}$ as immersion time. The micrograph of Figure 2(a) shows that the morphology of the coatings is relatively compact and defined zeta $\zeta$ and eta $\eta$ layers (outer layer) on the top of a delta $\delta$ layer and the gamma phase $(\Gamma)$ is not observed clearly [4]. The morphology of the $\zeta$ crystallites is coherent, and the $\delta$ phase is relative compact in which there are few cracks. The images of Figure 2(b) revealed that the coating obtained by adding $0.1 \mathrm{wt} \% \mathrm{Sn}$ in the molten zinc bath has alloyed layers finer than that formed with the traditional galvanized bath (Figure 2(a)). The coating is composed clearly of three alloyed layers of Fe- $\mathrm{Zn}$ intermetallic compounds, a very inner layer $\Gamma, \delta$ layer having $66.65 \mathrm{wt} \% \mathrm{Fe}$ and 33. $35 \mathrm{wt} \% \mathrm{Zn}$ and there is no $\mathrm{Sn}$ in this layer as shown in EDX analysis (Figure 3(a)).

Table 2. Effect of $\mathrm{Sn} w \mathrm{t} \%$ on the thickness of the alloyed layers.

\begin{tabular}{|c|c|c|c|c|c|}
\hline \multicolumn{2}{|c|}{ Sn wt(\%) } & \multirow{2}{*}{$\begin{array}{l}0 \\
-\end{array}$} & \multirow{2}{*}{$\begin{array}{c}0.1 \\
3\end{array}$} & \multirow{2}{*}{$\begin{array}{c}0.3 \\
3\end{array}$} & \multirow{2}{*}{$\begin{array}{c}0.5 \\
8\end{array}$} \\
\hline & Gamma $(\Gamma)$ & & & & \\
\hline $\begin{array}{c}\text { Thickness of } \\
\text { alloyed }\end{array}$ & Delta $(\delta)$ & 27 & 20 & 12 & - \\
\hline \multirow[t]{2}{*}{ layers $(\mu \mathrm{m})$} & $\operatorname{Zeta}(\zeta)$ & 33 & 28 & 24 & 38 \\
\hline & $\operatorname{Eta}(\eta)$ & 24 & 35 & 53 & 92 \\
\hline \multicolumn{2}{|c|}{ Average coating thickness $(\mu \mathrm{m})$} & 84 & 86 & 92 & 138.00 \\
\hline \multicolumn{2}{|c|}{ Standard deviation (S) } & 1.09 & 1.34 & 0.95 & 1.08 \\
\hline
\end{tabular}




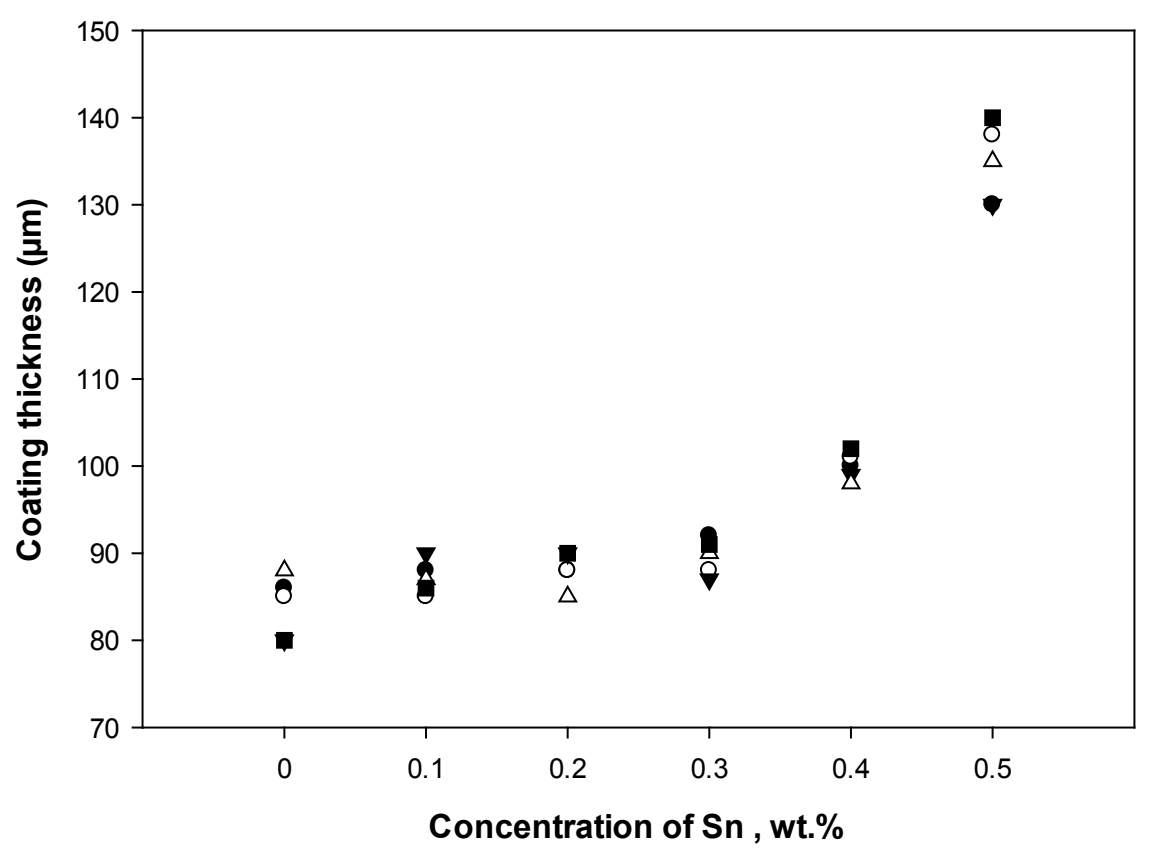

Figure 1. Effect of Sn concentration on the all coating thickness of galvanized layer formed at $460^{\circ} \mathrm{C}$ for $40 \mathrm{~s}$ immersion time.


Figure 2. Cross section of galvanized layer formed from molten $\mathrm{Zn}$ bath containing different concentration Sn operated at $460^{\circ} \mathrm{C}$ for $40 \mathrm{sec}$, where a) pure Zinc; b) Zn- $0.1 \mathrm{wt} \% \mathrm{Sn}$; c) $\mathrm{Zn}-0.3 \mathrm{wt} \% \mathrm{Sn}$; d) $\mathrm{Zn}-0.5 \mathrm{wt} \%$. 
The third intermetallic layer is a $\zeta$ having $3.76 \mathrm{wt} \% \mathrm{Sn}$ and $17 \mathrm{wt} \% \mathrm{Fe}$. The outer layer $\eta$ having $1.96 \mathrm{wt} \% \mathrm{Sn}$ and $8.84 \mathrm{wt} \% \mathrm{Fe}$ and has a fine structure (Figure 3(a)). Additionally, with increasing $\mathrm{Sn} \mathrm{wt} \%>0.2$, it's note that the thickness of gamma $(\Gamma)$ layer is very clearly formed (Figure 2(c) and Figure 2(d)) and the cracks on the coating have been formed. Also, EDX analysis illustrated that $\mathrm{Sn}$ is diffused into $\delta$ and $\zeta$ layers and outer layer $\eta$ as shown in Figure 3(b).

\subsection{Corrosion Behavior}

Tafel polarization, electrochemical impedance and salt spray studies were performed to evaluate the corrosion behavior of hot dip galvanized steel.

\subsubsection{Potentiodynamic Polarization Test}

The corrosion performance of galvanized steel with $\mathrm{Zn}$-Sn alloys containing different $\mathrm{Sn} w \mathrm{t} \%$ and compared with other galvanized steel was represented in Figure 4(a) and Figure 4(b) and Table 3. Figure 4(a) shows the Tafel lines of galvanized steel from molten $\mathrm{Zn}$ bath containing different $\mathrm{Sn}$ contents. From the results it is clear that the corrosion rate decreases with Sn adding compared with traditional galvanized steel. The lowest corrosion rate was found with $0.1 \mathrm{wt} \% \mathrm{Sn}$ addition. The Tafel line of the galvanized steel $\mathrm{Zn}-0.1$ and $0.2 \mathrm{wt} \% \mathrm{Sn}$ alloy indicates that a clear an anodic peak is observed at a potential of about $1.25 \mathrm{~V}$, they followed by a slight decrease of the current density. Notably, the anodic polarization behavior depends on the polarization potential and it includes a transition from active to passive region that include the formation of a film that could adsorb on the electrode surface and prevent its further dissolution so the current density decreases after these peaks. Moreover, the curves of pure galvanized and galvanized with high $\mathrm{Sn} \%(\geq 0.3 \mathrm{wt} \%)$ illustrated that three distinguished regions appeared in the anodic part of the polarization Tafel lines, the first one is the active dissolution region in which the current density increases with increasing the potential, the second region showed a monotonic increase in the current density with increasing the potential, and the third region indicated a large increase in the current density with increasing the potential. An obvious shift toward less current density values is observed in the anodic and cathodic Tafel lines due to the Sn adding to the galvanized bath compared to those of traditional galvanizing sample. Table 3 summarizes the characteristics parameters of the electrochemical test: the anodic Tafel slope values $\left(b_{a}\right)$, cathodic Tafel slope values $\left(b_{c}\right)$, corrosion potential $\left(E c_{\text {rr }}\right)$, corrosion current densities $\left(\mathrm{I}_{\text {corr }}\right)$ and corrosion rates in mmy-1 for mild steel, traditional galvanized steel, and galvanized steel with different $\mathrm{Zn}-\mathrm{Sn}$ alloys electrodes in $3.5 \% \mathrm{NaCl}$ at $25^{\circ} \mathrm{C}$. From Table 3 the values of $\mathrm{E}_{\text {corr }}$ seemed to be random with no discernable pattern, while a clear decrease in the corrosion current and corrosion rate are obtained for galvanized steel with $\mathrm{Zn}$-Sn alloys electrodes compared with traditional galvanized electrode. The corrosion rate of galvanized steel sheet with zinc bath containing $0.1 \mathrm{wt} \% \mathrm{Sn}$ is the lowest one compared to traditional galvanized steel. This improvement of the corrosion resistance can be attributed to the compact coated layer and the segregation of Sn at the grain which form Zn-Sn alloy as proved by EDX analysis (Figure 3). Moreover, Figure 4(b) shows Tafel lines of steel coated with $\mathrm{Zn}, \mathrm{Zn}-0.2 \mathrm{Al} \%$ and $\mathrm{Zn}-0.1 \mathrm{Sn} \%$ for compare the corrosion performance. Also, a lower corrosion current and corrosion rate are obtained for steel coated with $\mathrm{Zn}-0.1 \mathrm{wt} \%$ Sn alloy electrode. This corrosion rate is lower than that obtained with traditional galvanized steel and galvanized steel with $\mathrm{Zn}-0.2 \mathrm{wt} \% \mathrm{Al}$ electrode.

Table 3. Electrochemical parameters estimated from Tafel polarization curves.

\begin{tabular}{|c|c|c|c|c|c|c|}
\hline Tin concentration $(\%)$ & $\mathrm{E}_{\text {corr }}(\mathrm{V})$ & $\mathrm{I}_{\text {corr }}\left(\mathrm{Acm}^{-2}\right)$ & $\mathrm{R}_{\mathrm{p}}\left(\Omega \mathrm{cm}^{2}\right)$ & $\mathrm{b}_{\mathrm{a}}\left(\mathrm{Vdec}^{-1}\right)$ & $\mathrm{b}_{\mathrm{c}}\left(\mathrm{Vdec}^{-1}\right)$ & $\mathrm{C}_{\text {rate }}\left(\mathrm{mmy}^{-1}\right)$ \\
\hline Pure Galvanized & -1.32 & $1.727 \mathrm{E}-05$ & 2171 & 0.21 & 0.15 & 1.02 \\
\hline$+0.2 \mathrm{Al}$ & -1.28 & $8.88 \mathrm{E}-06$ & 3751 & 0.16 & 0.15 & 0.54 \\
\hline 0.1 & -1.25 & $4.27 \mathrm{E}-07$ & $5.316 \mathrm{E}+04$ & 0.114 & 0.097 & 0.03 \\
\hline 0.2 & -1.1782 & $1.686 \mathrm{E}-06$ & $1.594 \mathrm{E}+04$ & 0.116 & 0.133 & 0.10 \\
\hline 0.3 & -1.3153 & $1.259 \mathrm{E}-05$ & $0.2603 \mathrm{E}+04$ & 0.184 & 0.128 & 0.74 \\
\hline 0.5 & -1.3074 & $1.146 \mathrm{E}-05$ & $0.3042 \mathrm{E}+04$ & 0.186 & 0.141 & 0.68 \\
\hline
\end{tabular}



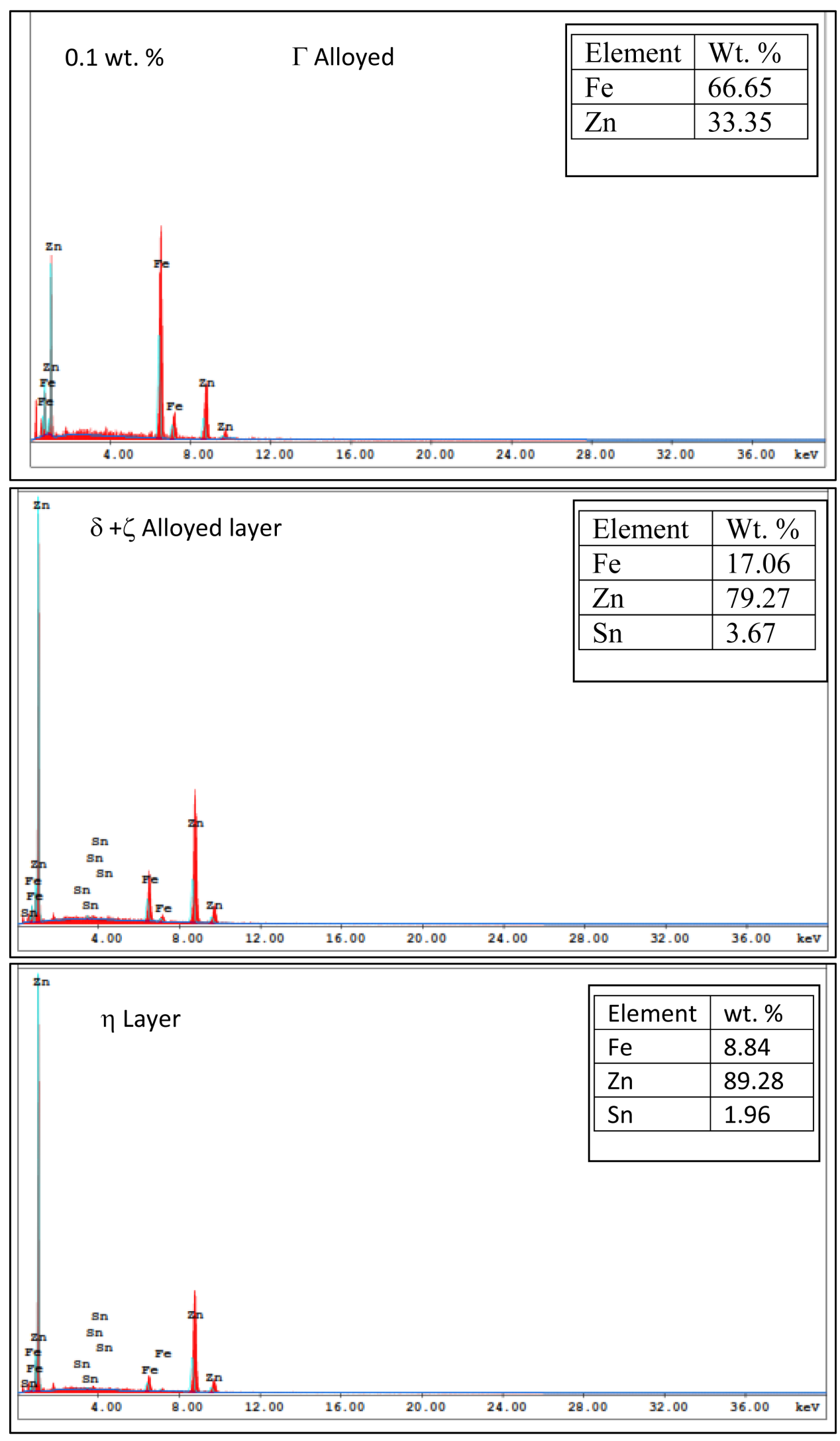

(a) 

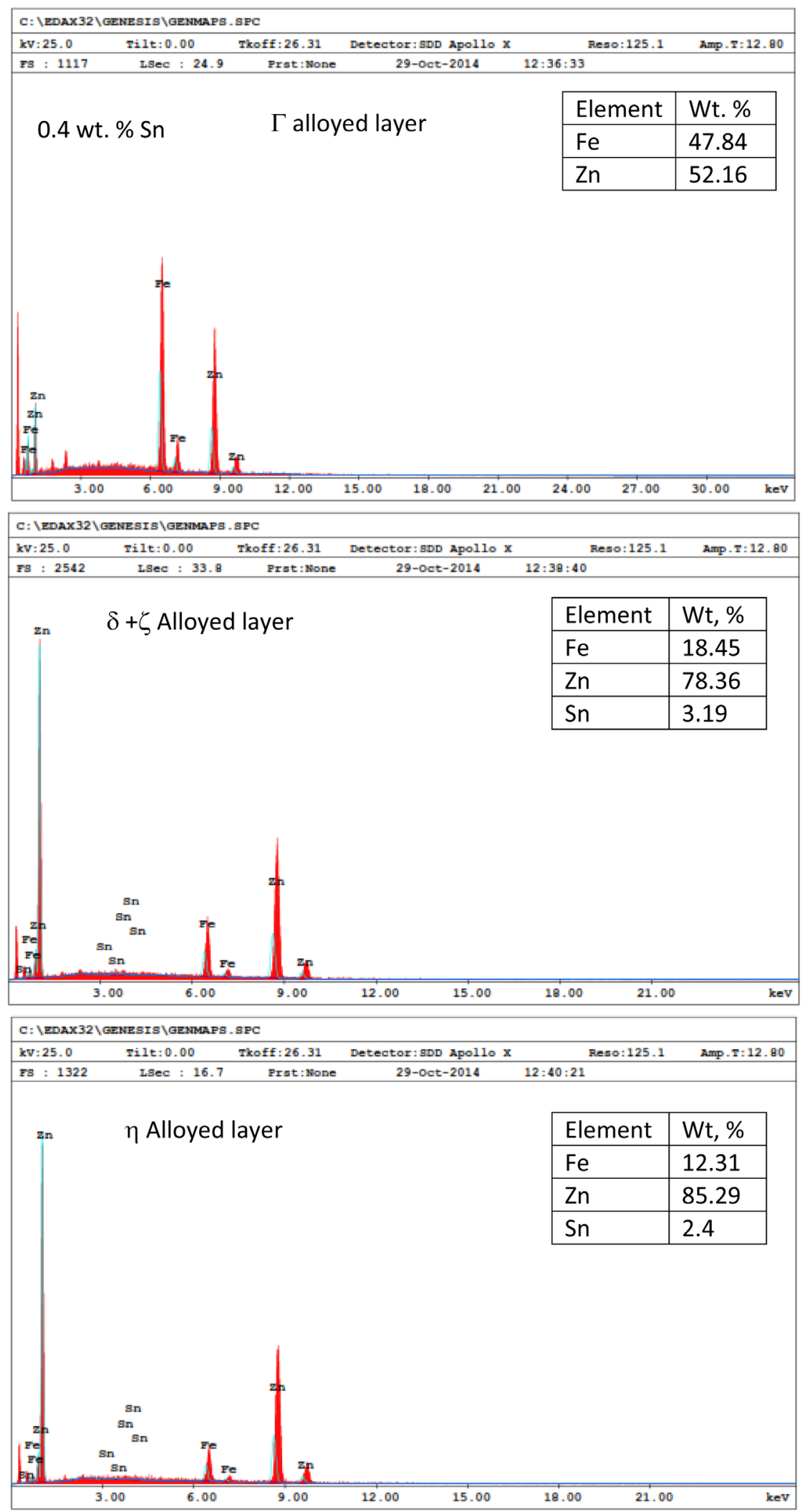

(b)

Figure 3. EDX analysis of galvanized layer formed from molten $\mathrm{Zn}$ containing low and high Sn Wt, \%, (a) 0.1 and (b) 0.4 . 


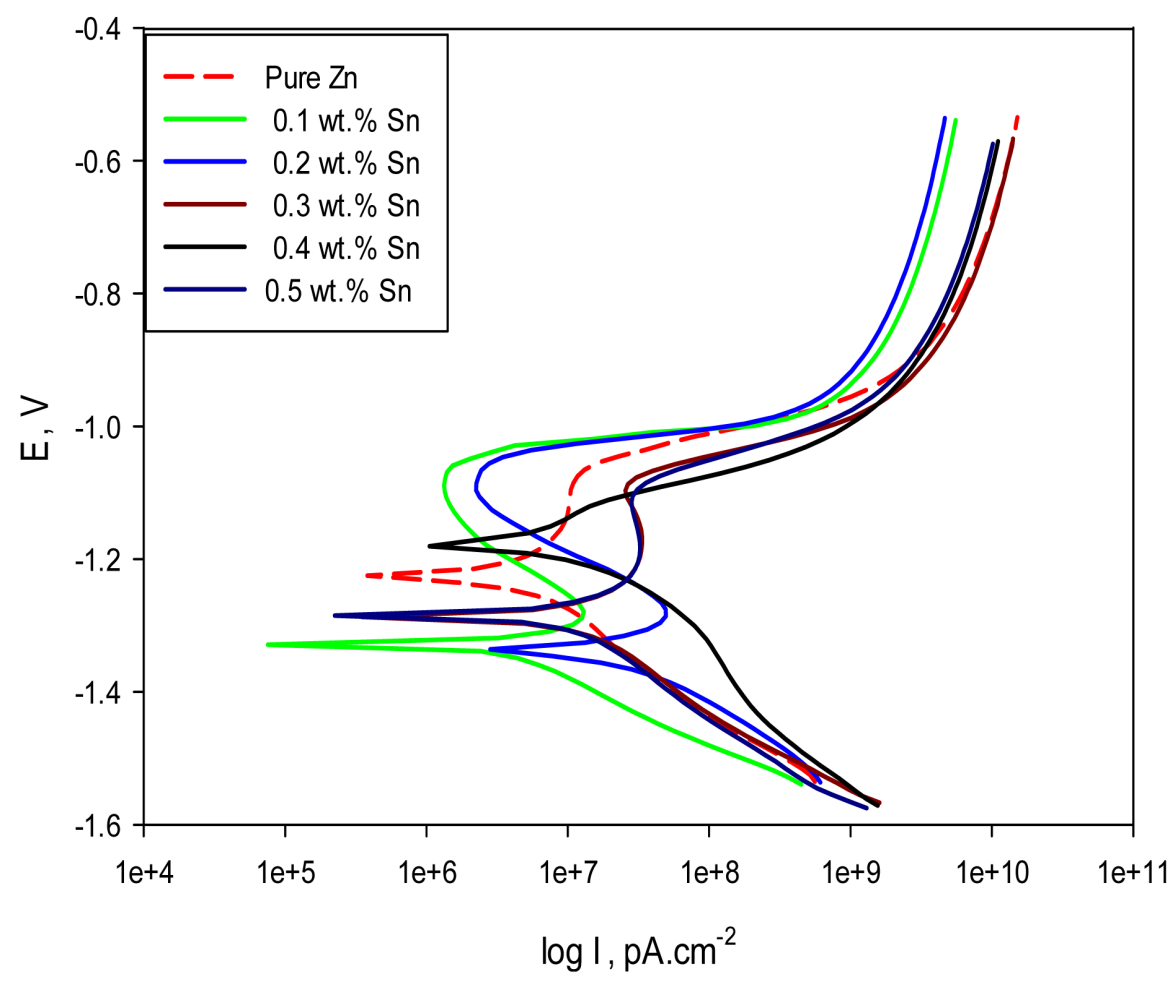

(a)

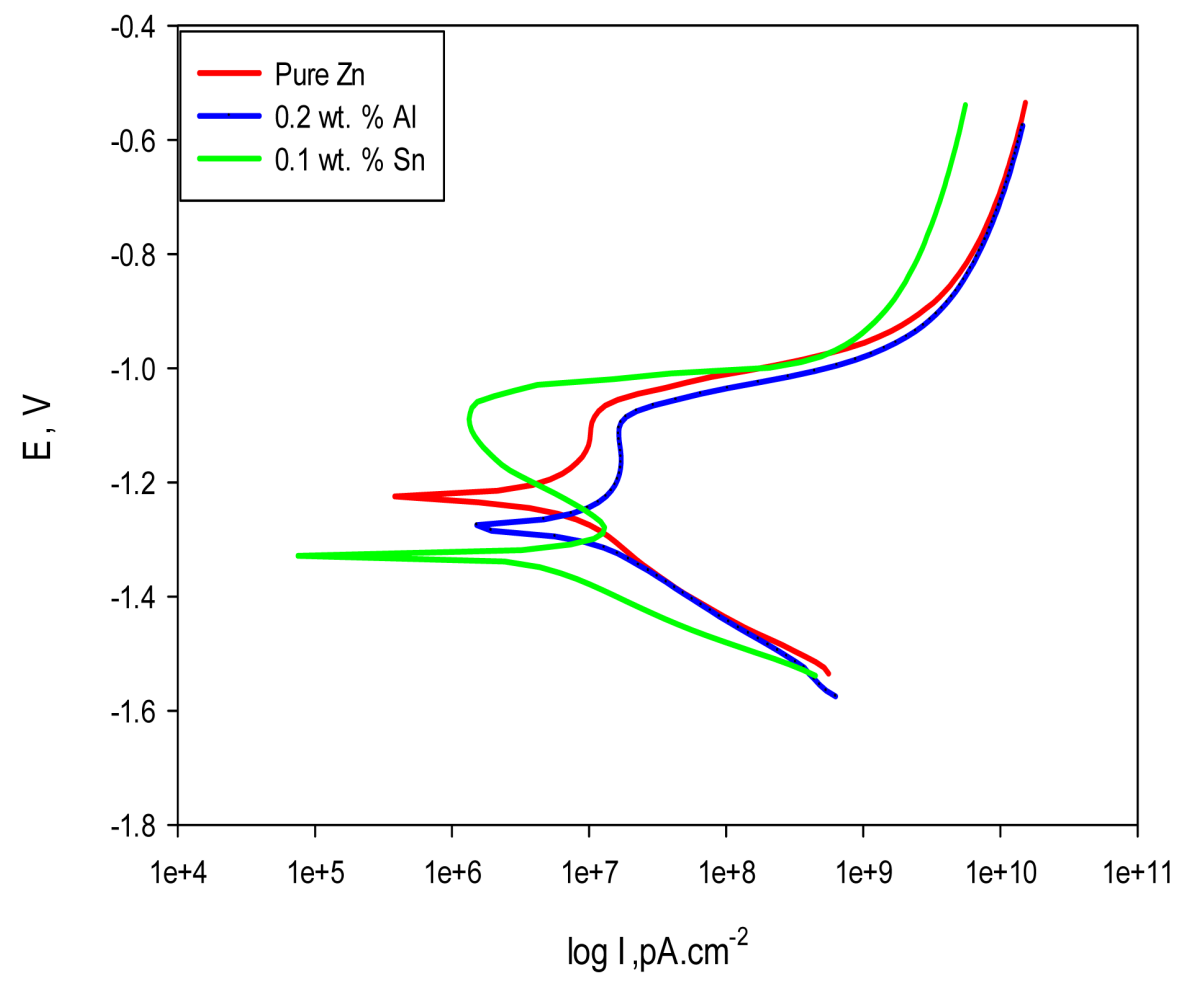

(b)

Figure 4. (a) Potentiodynamic polarization curves obtained to study the effect of Sn wt. \%; (b) compare between potentiodynamic polarization curves for steel sheet with traditional $\mathrm{Zn}$ coatings, galvanizing steel with $\mathrm{Zn}-0.2 \mathrm{Al}$ alloy and galvanizing steel with $\mathrm{Zn}-0.1 \mathrm{Sn}$ alloy at $460^{\circ} \mathrm{C}$, for $40 \mathrm{~s}$ immersion time in $3.5 \% \mathrm{NaCl}$ media. 


\subsubsection{EIS Measurements}

EIS was performed to test the corrosion behavior of all the investigated galvanized steel. The effect of Sn wt $\%$ on the corrosion resistance of $\mathrm{Zn}$-Sn coated steel sheet and compared with other galvanized steel was also measured through EIS test as illustrated in Figure 5 and Figure 6. EIS data are displayed as typical Nyquist $\left(Z_{\text {re }}\right.$ versus $Z_{\text {img }}$ ) plots (Figure 5(a) and Figure 5(b) and Figure 6(a)) and Bode plots (Figure 5(c) and Figure 6(b)), respectively. In this work, impedance measurement was carried out into aerated $3.5 \% \mathrm{NaCl}$ solution at the OCP of the respective coatings. To obtain the electrochemical parameters, the electrical equivalent circuits (EEC) in Figure 7 are used to fit the EIS data of the all investigated galvanized steel sheet. The calculated corrosion parameters are provided in Table 4. From Figure 5(a) the results suggest that two time constants present in the Nyquist plot for galvanized sample with molten $\mathrm{Zn}$ bath containing $0.1 \mathrm{wt} \% \mathrm{Sn}$ indicating the occurrence of two processes during corrosion. The EEC model with two RC couples (Figure 7(a)) was proposed to simulate this experimental curve and explain the corrosion process. As seen this circuit was based on two contributions, $\left(\mathrm{R}_{1} \mathrm{C}_{1}\right)$ and $\left(\mathrm{R}_{2} \mathrm{C}_{2}\right)$, related to high and low frequency time constant, respectively. According to the studied system, these time constants get different physical meaning. In this given equivalent circuit $\mathrm{R}$ is attributed to the electrolyte resistance between the reference electrode and the surface of the working electrode (Rs). The first

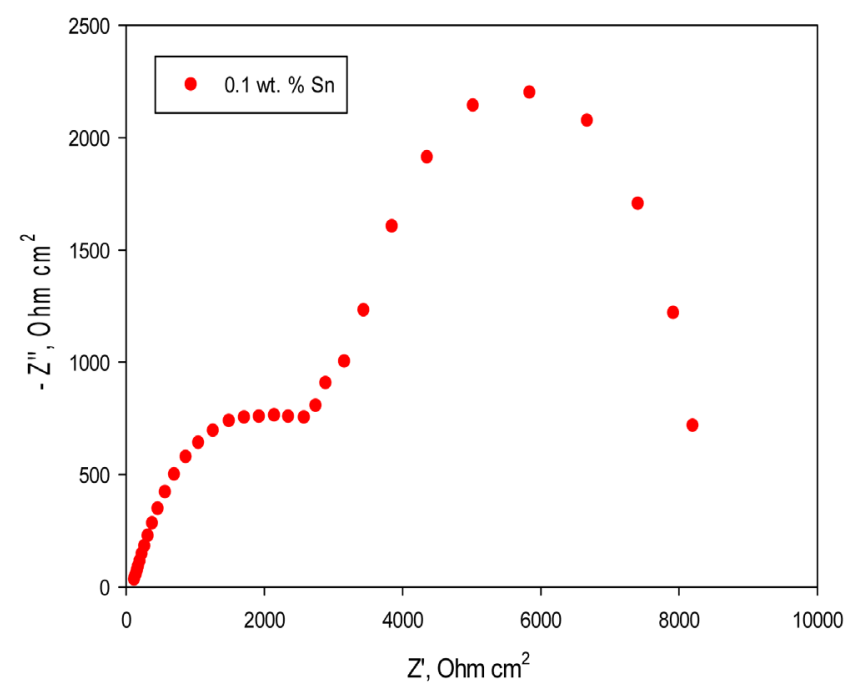

(a)

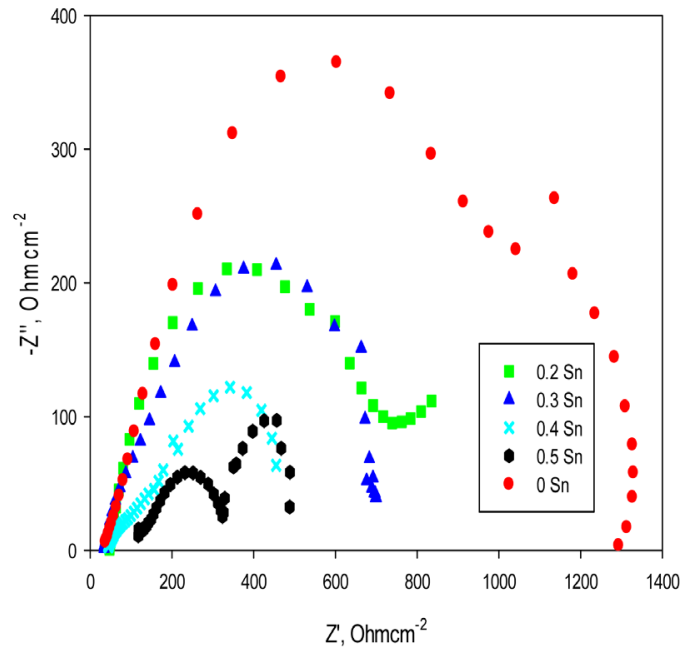

(b)

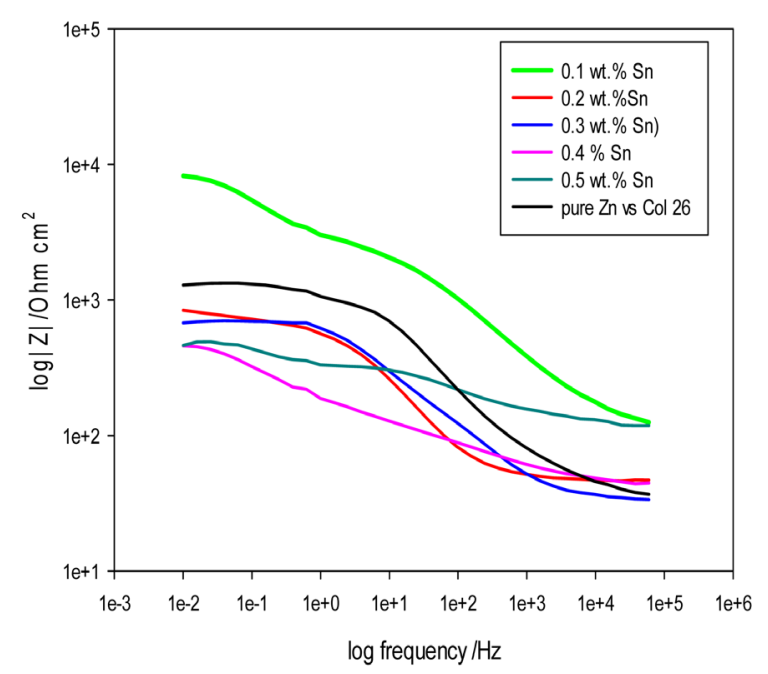

(c)

Figure 5. Electrochemical Impedance Nyquist and Bode obtained to study the effect of Sn wt.\% for galvanizing steel operated at $460^{\circ} \mathrm{C}$, for $40 \mathrm{~s}$ immersion time in $3.5 \% \mathrm{NaCl}$ media. 


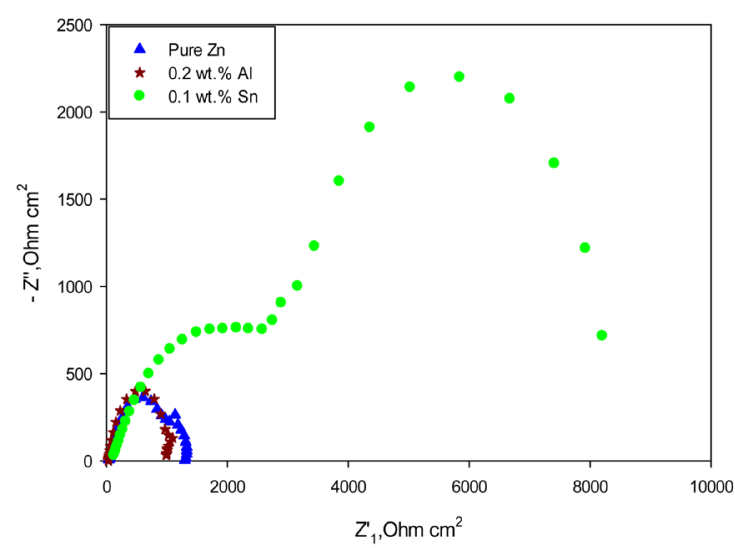

(a)

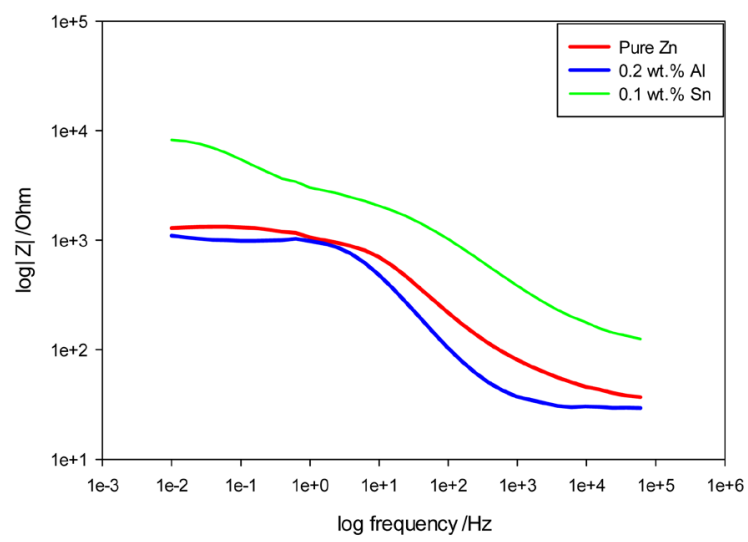

(b)

Figure 6. Electrochemical Impedance Nyquist and Bode obtained to compare between the behavior of traditional galvanized steel, galvanized steel with $\mathrm{Zn}-0.2 \mathrm{Al}$ alloy, and galvanized steel with $\mathrm{Zn}-0.1 \mathrm{Sn}$ alloy operated at $460^{\circ} \mathrm{C}$, for $40 \mathrm{~s}$ immersion time in $3.5 \% \mathrm{NaCl}$ media.

Table 4. Corrosion parameters determined by fitted impedance spectra of $\mathrm{Zn}$ coatings in $3.5 \% \mathrm{NaCl}$ solution.

\begin{tabular}{|c|c|c|c|c|c|c|c|}
\hline \multirow{2}{*}{ Parameters } & \multirow{2}{*}{ Traditional Zn } & \multirow{2}{*}{ Traditional $\mathrm{Zn}+0.2 \mathrm{Al}$} & \multirow{2}{*}{$\mathrm{Zn}+0.1 \mathrm{Sn}$} & \multirow{2}{*}{$\mathrm{Zn}+0.2 \mathrm{Sn}$} & $\mathrm{Zn}$ & $\mathrm{Zn}$ & $\mathrm{Zn}$ \\
\hline & & & & & $+0.3 \mathrm{Sn}$ & $+0.4 \mathrm{Sn}$ & $+0.5 \mathrm{Sn}$ \\
\hline $\mathrm{R}_{\mathrm{s}}\left(\Omega \mathrm{cm}^{2}\right)$ & $4.399 \mathrm{E}-01$ & $5.33 \mathrm{E}+01$ & $7.5 \mathrm{E}+02$ & $7.01 \mathrm{E}+01$ & $7.69 \mathrm{E}+01$ & $8.37 \mathrm{E}+01$ & $1.48 \mathrm{E}+02$ \\
\hline $\mathrm{R}_{1}\left(\Omega \mathrm{cm}^{2}\right)$ & $1.334 \mathrm{E}+03$ & $9.51 \mathrm{E}+02$ & $3.18 \mathrm{E}+03$ & $5.63 \mathrm{E}+02$ & $5.68 \mathrm{E}+02$ & $3.22 \mathrm{E}+02$ & $1.699 \mathrm{E}+02$ \\
\hline $\mathrm{R}_{2}\left(\Omega \mathrm{cm}^{2}\right)$ & - & & $5.72 \mathrm{E}+03$ & - & $4.02 \mathrm{E}+02$ & - & $1.79 \mathrm{E}+02$ \\
\hline $\mathrm{C}_{1}\left(\mathrm{Fcm}^{-2}\right)$ & $1.27 \mathrm{E}-04$ & $3.08 \mathrm{E}-05$ & $5.76 \mathrm{E}-05$ & $5.59 \mathrm{E}-05$ & $1.82 \mathrm{E}-05$ & $2.89 \mathrm{E}-03$ & $1.41 \mathrm{E}-05$ \\
\hline $\mathrm{C}_{2}\left(\mathrm{Fcm}^{-2}\right)$ & - & - & $1.94 \mathrm{E}-04$ & - & $1.55 \mathrm{E}-04$ & - & $6.34 \mathrm{E}-03$ \\
\hline $\mathrm{W}$ & $5.25 \mathrm{E}+03$ & - & - & $4.68 \mathrm{E}-05$ & - & - & - \\
\hline Error & $1.34 \mathrm{E}-07$ & $5.23 \mathrm{E}-09$ & $6.4 \mathrm{E}-08$ & $1.75 \mathrm{E}-08$ & $9.90 \mathrm{E}-09$ & $5.66 \mathrm{E}-07$ & $5.42 \mathrm{E}-09$ \\
\hline $\mathrm{n}$ & 0.90 & 0.98 & 0.90 & 0.97 & 0.95 & 0.98 & 0.96 \\
\hline
\end{tabular}

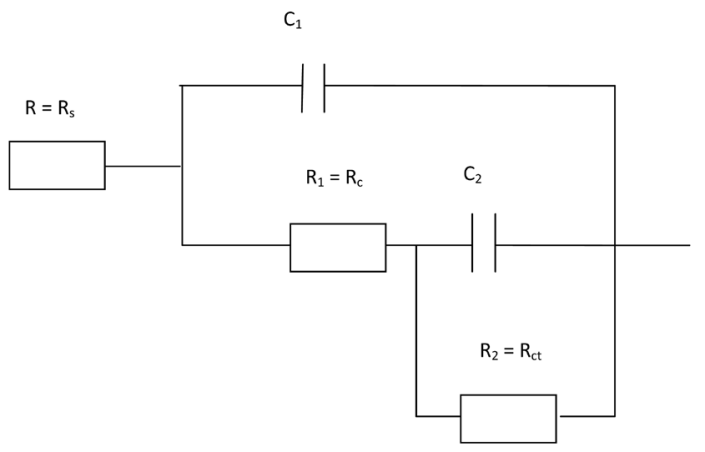

(a)

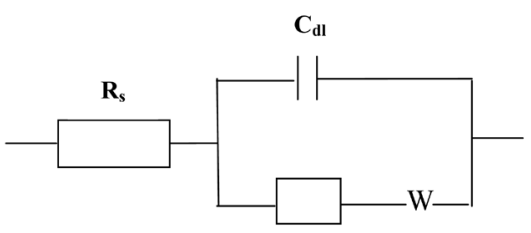

$\mathbf{R}_{\mathbf{p}}$

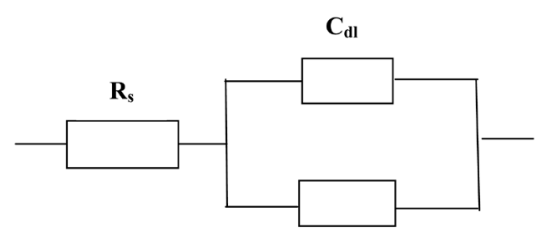

$\mathbf{R}_{\mathbf{p}}$

(b)

Figure 7. Electrical equivalent circuit used to simulate the recorded EIS data where (a) fitting of two time constant and (b) fitting of one time constant. 
time constant on $\mathrm{Zn}$ layer is attributed to the compact inner layer of surface oxide (corrosion product) compounds which can be partially protective, $R_{1}$ and $C_{1}$ were associated to the coating Layers impedance represented by resistive $\left(R_{c}\right)$ and capacitive $\left(C_{c}\right)$ elements. While, the second time is linked with the double layer capacitance $\left(\mathrm{C}_{\mathrm{dl}}\right)$ at the electrolyte/coated surface interface and the charge transfer resistance of the coated layer $\left(\mathrm{R}_{\mathrm{ct}}\right)$, respectively [27]-[29]. The coating capacitance $\left(\mathrm{C}_{\mathrm{c}}\right)$ defined by the following equation:

$$
C_{c}=e_{0} e_{r} A / d
$$

where, $\varepsilon_{0}$ is the permittivity of the free space, $\varepsilon_{r}$ is the relative permittivity or coating dielectric constant, $\mathrm{A}$ is the coating surface area and $d$ its thickness. The total polarization resistance $\left(R_{p}\right)$ is the sum of $R_{c}$, Rct. In particular, this coating has higher $R_{p}$ and lower $C_{d l}$ value, and it follows the same trend as observed in polarization study. Additionally, it's clearly that, EIS analysis of pure galvanizing coating indicates that a one-time constant is clearly observed as shown in Figure 5(b). To better understand the impedance, Bode representations of the impedance spectra (Figure 5(c) and Figure 6(b)) shows the relationship between the values of the impedance and frequency. The value of impedance was low in the high frequency, while in the low frequency region, the values of the impedance slightly increased [30]. While, with increasing Sn wt $\%$ to 0.2 EIS results indicate that a one- time constant is clearly observed in the high-frequency region and a straight line (Warburg) in the low frequency region is observed in the Nyquist plots as shown in Figure 5(b). This time constant is attributed to the charge transfer resistance $\left(R_{p}\right)$, whereas the Warburg impedance is attributed to the diffusion of the anodic and cathodic reaction products from the solution to the electrode surface. The presence of the Warburg (W) impedance in the circuit, confirms also that the mass transport is limited by the surface protective film. Moreover, with increasing $\mathrm{Sn} w \mathrm{t} \%$ from 0.3 to $0.5 \mathrm{wt} \%$, EIS results indicated that a two-time constant also is clearly observed as shown in Figure 5(b). The EEC model (Figure 7(a)) was proposed to simulate these experimental curves. Also, the polarization resistance values $\left(\mathrm{R}_{\mathrm{p}}\right)$ are much higher for the galvanized steel in Zn-0.1 Sn alloy than that of galvanized steel when $\mathrm{Sn} w \mathrm{t} \%>0.1$. Additionally, increasing $\mathrm{Sn}$ in the galvanized bath from 0.3 to $0.5 \mathrm{wt} \%$ led to decrease the corrosion resistance of $\mathrm{Zn}$-Sn coated steel sheet owing to the decrease of $\mathrm{R}_{\mathrm{p}}$ and an increase $\mathrm{C}_{\mathrm{d} \mathrm{d}}$. The decreasing in the corrosion resistance property can be attributed to the appearance of crack in the cross section which leads to increase the interaction between $\mathrm{NaCl}$ solution and the investigated samples; the dissolution rate of metallic coatings is very sensitive to its surface morphology [31]. Figure 6 shows a comparison between EIS results of galvanized steel with $\mathrm{Zn}-0.1 \mathrm{wt} \% \mathrm{Sn}$ and traditional galvanized steel. The EIS results reveal that pure galvanized steel and $\mathrm{Zn}-0.2 \mathrm{wt} \% \mathrm{Al}$ galvanized steel have a one-time constant. The highest polarization resistance value ( $\mathrm{Rp}$ ) is for the galvanized steel with $\mathrm{Zn}-0.1 \mathrm{wt} \% \mathrm{Sn}$ alloy. These results show that the change in morphology of the alloyed layer due to the addition of $0.1 \mathrm{Sn} w \mathrm{w} \%$ makes $\mathrm{Zn}$ deposits considerably resistant toward the external aggressive media as compared to steel sheet. This analysis revealed that the addition of $\mathrm{Sn}$ into the $\mathrm{Zn}$ bath remarkably influenced the corrosion resistance property of the hot dip Zn coatings [31].

\subsubsection{Salt Spray Test}

Salt spray test is the best method to predict the performance of hot-dip galvanized steel in various environments using ASTM B117 specification. The corrosion resistance of galvanized coatings produced from molten baths with different $\mathrm{Sn} w \mathrm{t} \%$ has been investigated using salt spray test. The samples are inserted into $3.5 \% \mathrm{NaCl}$ salt solution at a constant room temperature, $100 \%$ Relative humidity, and 1 atmospheric pressure. Results of the salt spray test reveal that after $700 \mathrm{hrs}$. holding time, there was white rust (about 95\%) and no red rust appeared on the surface for all galvanized samples produced, indicating a good corrosion resistance. This mean that by using salt spray test all the galvanized steel sheets without or with adding Sn exhibited good corrosion resistance and can't estimate the corrosion rate to show the different between them.

To identify the phase composition of corrosion products of galvanized layer formed with molten $\mathrm{Zn}$ and $\mathrm{Zn}-0.1 \mathrm{wt} \% \mathrm{Sn}$ alloy hot dip galvanized steel sheet, the XRD was conducted. Figure 8 shows the results of XRD of the corrosion products of the coating Layers after $700 \mathrm{hrs}$ in the salt spray chamber which simulates the environment that containing much salt. The results reveal that the corrosion products with $\mathrm{Zn}-0.1 \mathrm{wt} \% \mathrm{Sn}$ alloy basically $\mathrm{Zn}_{5}(\mathrm{OH})_{8} \mathrm{Cl}_{2} \mathrm{H}_{2} \mathrm{O}$ (Simonkolleit), $\mathrm{ZnCl}_{2}$ [32], and $\left(\mathrm{Sn}_{3} \mathrm{O}_{2}\left(\mathrm{Cl}_{4}\right)_{4}\right)_{2}$ which suppresses corrosion of galvanized layer and increase the corrosion resistance. 


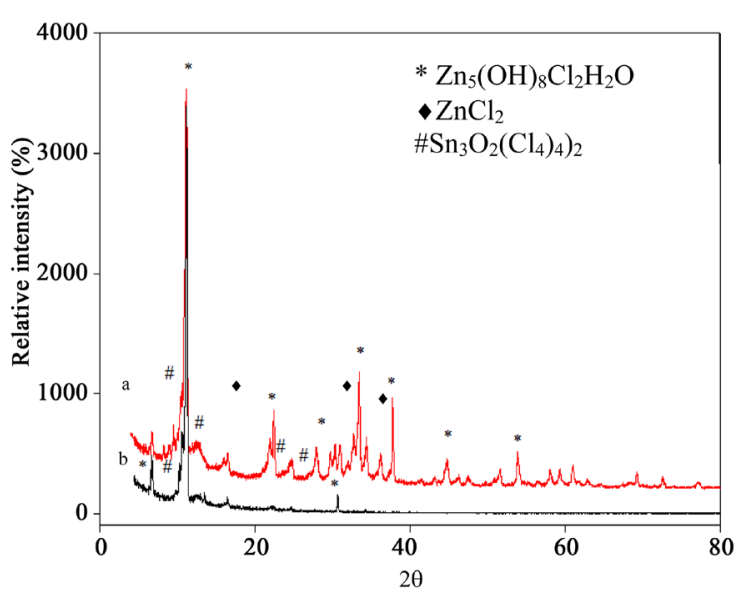

Figure 8. XRD analysis patterns of $\mathrm{Zn}-\mathrm{Sn}$ galvanized steel with different $\mathrm{Sn}$ wt $\%$ after 700 hs salt spray test, where a) with molten bath containing $0.1 \mathrm{Sn} w \mathrm{t} \%$, and b) $\mathrm{Zn}$.

\section{Conclusion}

The role of the process parameters has been affecting the structural characteristics and the properties of the coating Layers. The results of this investigation suggest some general conclusions like: the presence of Sn in the molten $\mathrm{Zn}$ improves bath fluidity and leads to a better wettability of molten $\mathrm{Zn}$-Sn alloy. Coatings obtained by $\mathrm{Zn}-\mathrm{Sn}$ alloy are characterized by bright and smooth surfaces as traditional galvanizing coatings. The addition of $\mathrm{Sn}$ in the composition of the galvanized coating Layers led to producing a fine, uniform and defect free morphology. Moreover, the morphology of the alloyed layers with the addition of Sn has been changed. Sn was used as additive to enhance the corrosion resistance property of hot dip $\mathrm{Zn}$ coatings. Sn concentration must be kept at $0.1 \mathrm{wt} \%$ in the Zn bath to obtain the desired good corrosion resistance galvanized steel samples.

\section{References}

[1] Baboian, R. (1995) Corrosion Tests and Standards: Application and Interpretation. ASTM, Philadelphia, 513.

[2] Pistofidis, N., Vourlias, G., Konidaris, S., Pavlidou, E., Stergiou, A. and Stergioudis, G. (2006) Microstructure of Zinc Hot-Dip Galvanized Coatings Used for Corrosion Protection. Materials Letters, 60, 786-789. http://dx.doi.org/10.1016/j.matlet.2005.10.013

[3] Peng, B.C., Wang, J.H., Su, X.P., Li, Z. and Yin, F.C. (2008) Effects of Zinc Bath Temperature on the Coatings of Hot-Dip Galvanizing. Surface and Coatings Technology, 202, 1785-1788. http://dx.doi.org/10.1016/j.surfcoat.2007.07.044

[4] Marder, A.R. (2000) The Metallurgy of Zinc-Coated Steel. Progress in Materials Science, 45, 191-271. http://dx.doi.org/10.1016/S0079-6425(98)00006-1

[5] Fratesi, R., Ruffini, N., Malavolta, M. and Bellezze, T. (2002) Contemporary Use of Ni and Bi in Hot-Dip Galvanizing. Surface and Coatings Technology, 157, 34-39. http://dx.doi.org/10.1016/S0257-8972(02)00137-8

[6] Porter, F.C. (1991) Zinc Handbook: Properties, Processing, and Use in Design. Marcel Dekker, New York.

[7] Borzillo, A.R. and Hahn Jr., W.C. (1969) Growth of the Aluminum-Rich Alloy on Mild Steel during Galvanizing in Zinc That Contains Aluminum. Transactions of the ASM, 62, 729-739.

[8] Allegra, L. and Zoccola, J.C. (1983) Aluminum Zinc Coated Sheet Steel for Automotive Applications. Materials Performance, 22,5 .

[9] Shibli, S.M.A., Jayalekshmi, A.C. and Remya, R. (2007) Electrochemical and Structural Characterization of the Mixed Oxides-Reinforced Hot-Dip Zinc Coating. Surface and Coatings Technology, 201, 7560-7565. http://dx.doi.org/10.1016/j.surfcoat.2007.02.028

[10] Vourlias, G., Pistofidis, N., Stergioudis, G. and Tsipas, D. (2004) The Effect of Alloying Elements on the Crystallization Behavior, and on the Properties of Galvanized Coatings. Crystal Research \& Technology, 39, 23-29. http://dx.doi.org/10.1002/crat.200310144

[11] Ahmadi, N.P. and Rafiezadeh, E. (2009) Effect of Aluminum on Microstructure and Thickness of Galvanized Layers on Low Carbon Free Silicon Steel. International Journal of ISSI, 6, 25-29.

[12] Shibli, S.M.A. and Manu, R. (2005) Process and Performance Improvement of Hot Dip Zinc Coating by Dispersed 
Nickel in the under Layer. Surface and Coatings Technology, 197, 103-108.

http://dx.doi.org/10.1016/j.surfcoat.2004.10.115

[13] Shibli, S.M.A., Manu, R. and Beegum, S. (2008) Studies on the Influence of Metal Oxides on the Galvanic Characteristics of Hot-Dip Zinc Coating. Surface and Coatings Technology, 202, 1733-1737. http://dx.doi.org/10.1016/j.surfcoat.2007.07.033

[14] Guan, C., Li, J., Tan, N., Zhang, S.G. and Zhang, W.Y. (2015) Effect of Bath Aluminum Concentration on the Galvanizing of Hydrogen Reduced Hot Rolled Steel without Acid Pickling. Surface and Coatings Technology, 279, $142-149$. http://dx.doi.org/10.1016/j.surfcoat.2015.08.044

[15] Pistofidis, N., Yourlias, G., Konidaris, S., Pavilidou, E., Stergiou, A. and Stergioudis, G. (2007) The Effect of Bismuth on the Structure of Zinc Hot-Dip Galvanized Coatings. Materials Letters, 61, 994-997. http://dx.doi.org/10.1016/j.matlet.2006.06.029

[16] Sere, P.R., Culcasi, J.D., Elsner, C.I. and Di Sarli, A.R. (1999) Relationship between Texture and Corrosion Resistance in Hot-Dip Galvanized Steel Sheets. Surface and Coatings Technology, 122, 143-149. http://dx.doi.org/10.1016/S0257-8972(99)00325-4

[17] Wang, K.K., Hsu, C.W., Chang, L., Gan, D. and Yang, K.C. (2013) Role of Al in Zn Bath on the Formation of the Inhibition Layer during Hot-Dip Galvanizing for a 1.2Si-1.5Mn Transformation-Induced Plasticity Steel. Applied Surface Science, 285, 458-468. http://dx.doi.org/10.1016/j.apsusc.2013.08.077

[18] Ghuman, A.R.P. and Goldstein, J.I. (1971) Reaction Mechanisms for the Coatings Formed During the Hot Dipping of Iron in 0 to 10 Pct Al-Zn Baths at $450^{\circ}$ to $700^{\circ}$ C. Metallurgical Transactions, 2, 2903-2914. http://dx.doi.org/10.1007/BF02813270

[19] Shukla, S.K., Deepa, M. and Kumar, S. (2012) Effect of Mg Addition (in Zinc Bath) on Galvanized Sheet Quality. International Journal of Materials Engineering, 2, 105-111. http://dx.doi.org/10.5923/j.ijme.20120206.05

[20] Li, S., Gao, B., Tu, G., Hao, Y., Hu, L. and Yin, S. (2011) Study on the Corrosion Mechanism of Zn-5Al-0.5Mg0.08Si Coating. Journal of Metallurgy, 2011, Article ID: 917469. http://dx.doi.org/10.1155/2011/917469

[21] Elvins, J., Spittle, J.A., Sullivan, J.H. and Worsley, D.A. (2008) The Effect of Magnesium Additions on the Microstructure and Cut Edge Corrosion Resistance of Zinc Aluminium Alloy Galvanised Steel. Corrosion Science, 50, 1650-1658. http://dx.doi.org/10.1016/j.corsci.2008.02.005

[22] Urednicek, M. and Kirkaldy, J.S. (1973) An Investigation of the Phase Constitution of Iron-Zinc-Aluminium at $450^{\circ} \mathrm{C}$. Zeitschrift für Metallkunde, 64, 419-426.

[23] Chang, S. and Shin, J.C. (1994) The Effect of Antimony Additions on Hot Dip Galvanized Coatings. Corrosion Science, 36, 1425-1436. http://dx.doi.org/10.1016/0010-938X(94)90190-2

[24] Kania, H. and Liberski, P. (2012) Synergistic Influence of Al, Ni, Bi and Sn Addition to a Zinc Bath upon Growth Kinetics and the Structure of Coatings. IOP Conference Series: Materials Science and Engineering, 35, Article ID: 012004. http://dx.doi.org/10.1088/1757-899x/35/1/012004

[25] Katofiris, N. and Papadimitriou, G. (1996) Effect of the Sn Addition Was Investigated. Surface and Coatings Technology, 78, 185-195.

[26] Guttmann, M. (1994) Diffusive Phase Transformations in Hot Dip Galvanizing. Materials Science Forum, 155-156, 527-548. http://dx.doi.org/10.4028/www.scientific.net/MSF.155-156.527

[27] Deflorian, F., Miskovic-Stankovic, V.B., Bonora, P.L. and Fedrizzi, L. (1994) Degradation of Epoxy Coatings on Phosphatized Zinc-Electroplated Steel. Corrosion, 50, 438-446. http://dx.doi.org/10.5006/1.3293522

[28] Lin, C., Nguyen, T. and McKnight, M.E. (1992) Relation between AC Impedance Data and Degradation of Coated Steel. 1. Effects of Surface Roughness and Contamination on the Corrosion Behavior of Epoxy-Coated Steel. Progress in Organic Coatings, 20, 169-186. http://dx.doi.org/10.1016/0033-0655(92)80003-F

[29] Callow, L.M. and Scantlebury, J.D. (1981) Electrochemical Impedance on Coated Metal Electrodes. Part 1: Polarization Effects. JOCCA, 64, 83-87.

[30] Zhang, X., Pehkonen, S.O., Kocherginsky, N. and Ellis, G.A. (2002) Copper Corrosion in Mildly Alkaline Water with the Disinfectant Monochloramine. Corrosion Science, 44, 2507-2528. http://dx.doi.org/10.1016/S0010-938X(02)00021-5

[31] Ishikawa, T., Ueda, M., Kandori, K. and Nakayama, T. (2007) Air Permeability of the Artificially Synthesized Zn-Al-Mg alloy Rusts. Corrosion Science, 49, 2547-2556. http://dx.doi.org/10.1016/j.corsci.2006.12.008

[32] Li, B., Dong, A., Zhu, G., Chu, S., Qian, H., Hu, C., Sun, B. and Wang, J. (2012) Investigation of the Corrosion Behaviors of Continuously Hot-Dip Galvanizing Zn-Mg Coating. Surface and Coatings Technology, 206, 3989-3999. http://dx.doi.org/10.1016/j.surfcoat.2012.03.079 